\title{
9. Media freedom and state control in Tonga
}

\section{ABSTRACI}

The Tongan Constitution guarantees free speech and media freedom but this guarantee has often been misunderstood and misinterpreted by the media industry, the government and politicians alike. Freedom of speech was integrated into the Constitution from the beginning in 1875. However, as history has shown, this freedom has often been altered to silence opposition and critics' voices. As early as 1882, the Tongan media had their first confrontation with the government and in 2003 saw a parallel incident unfolding. This article examines the influence of state control on the media in Tonga through an analysis of two case studies from different eras in Tongan history: the Niuvakai newspaper in 1882 and the Taimi ' $O$ Tonga newspaper in 2003.

Keywords: constitution, freedom of speech, media freedom, Taimi 'o Tonga, Niuvakai,

\section{SIONE FATANITAVAKE VIKILANI}

Ritsumeikan Asia Pacific University, Japan

$\mathrm{T}$

THE NEWS media in Tonga has come a long way since its introduction in the mid-1980s. However, little has changed since then, espelater, the media faces similar problems as confronted it in its early days. This article examines two different case studies more than a century apart but demonstrating similar problems regarding media freedom in Tonga. It also examines the parallels between these two cases which can substantiate the argument that government interference hinders media freedom in Tonga. The case studies of the Taimi 'o Tonga newspaper and the Niu Vakai emphasise what Siebert et al. (1956, p. 7) argued, that the press and other media in any country always take on the 'form and environment of the social and political structures within which they operate'. They argue that in order to understand 
how the media works, one should have knowledge of the socio-political system of that country.

Siebert et al. (1956) examined what they call the four basic theories of the press which also apply to other media. The first of these theories is the authoritarian theory which suggests that truth is regarded as the prerogative of the powerful elite. It is the press or the media's duty to support the government in power and the elite. According to Siebert, the authoritarian state system requires direct government control of the mass media. This type of situation is especially easy to recognise in pre-democratic societies where the government consists of a limited and small ruling class. The media in an authoritarian system are not allowed to print or broadcast anything offensive to the government because the government will punish anyone who questions the state's ideology.

Although the form of government in Tonga is a Constitutional Monarchy, the powers given to the King by the Constitution make his rule rather more authoritarian, close to an absolute monarchy. It may seem extreme to apply the word 'authoritarian' in Tonga's case, but it is appropriate taking into account the form of government. This was true in the two periods analysed here, though recently government has improved its relationship with the media. In Tonga, the government does not have direct control over the mass media apart from its own media. As will be discussed below, the government in these two different periods went as far as amending the Constitution to punish those that questioned its authority and its ideologies.

The second of Siebert's theories is the libertarian theory. Here the media is free, the government encourages criticism of itself, and everyone is free to voice their own opinions.

The third theory is the Soviet theory, where private ownership of the media is not really encouraged by the state, and where the media have a responsibility to the state and the people. This is based on the postulates of Marx and Engels.

The fourth theory is social responsibility, where the journalist is responsible both to the society and the government.

Tonga's current situation could be said to fall somewhere between social responsibility and authoritarian, based on the current form of government. In the Constitution, the freedom of the press is guaranteed but in practice the government can largely do whatever it wants, shifting Tonga towards the authoritarian paradigm. The timing of amendments made to the Freedom of 
the Press Clause in 2002 of the Constitution supports the argument proposed here. The first and the last amendments were made when the Niu Vakai and the Taimi 'o Tonga were beginning to gain popularity, and also when both were highly critical of the government.

It is also important to note that in almost all countries in the Pacific, like Tonga, the Constitution guarantees the freedom of the media. However, interpretations of this freedom often cause tensions and conflicts between the media and the government. Clause 7 of the Tongan Constitution guarantees freedom of the media.

When the Constitution was enacted in 1875 it read:

It shall be lawful for all people to speak write and print their opinions and no law shall ever be enacted to restrict this liberty. There shall be freedom of speech and of the press for ever but nothing in this clause shall be held to outweigh the law of slander or the laws for the protection of the King and the Royal Tonga Family. (Clause 7, Tongan Constitution)

In 1882, Shirley Baker, a former Wesleyan missionary who became premier of Tonga, amended Clause 7 by passing two acts through Parliament with the consent of the King. The first was An Act Relative to Newspapers and the second was An Act Relative to Sedition (Barney, 1974, p. 355). As will be discussed in the case study, the acts were aimed at the Niu Vakai newspaper and its editor who was an expatriate.

The freedom of the press clause of the Constitution remained for another century before it was amended again in 1990. The amendment in 1990 was just to replace the word 'slander' with 'defamation' and 'official secrets'. This did not cause any commotion because the amendment did not change anything but instead added official secrets and defamation. Interestingly, the inclusion of defamation was not needed because there is a separate defamation law.

\section{After the 1990 Amendment:}

7. It shall be lawful for all people to speak write and print their opinions and no law shall ever be enacted to restrict this liberty. There shall be freedom of speech and of the press for ever but nothing in this clause shall be held to outweigh the law of defamation, official secrets or the laws for the protection of the King and the Royal Family. 


\section{After the 2003 Amendment, the act now reads:}

7. (1) It shall be lawful for all people to speak write and print their opinions and no law shall ever be enacted to restrict this liberty. There shall be freedom of speech and of the press for ever but nothing in this clause shall be held to outweigh the law of slander or the laws for the protection of the King and the Royal Family.

(2) It shall be lawful, in addition to the exceptions set out in sub-clause (1), to enact such laws as are considered necessary or expedient in the public interest, national security, public order, morality, cultural traditions of the Kingdom, and privileges of the Legislative Assembly and to provide for contempt of Court and the commission of any offence.

(3) It shall be lawful to enact laws to regulate the operation of any media.

The addition of sub-section (3) in Clause 7 made way for the Media Operators' Act and also the Newspaper Act. Lopeti Senituli, former director of the Tonga Human Rights and Democracy Movement and now press secretary and political adviser to the Prime Minister, argued that there was no need for the amendment because the government had at its disposal legislation to protect itself, the royal family, and the public in general from media abuse (Senituli, 2003, Planet Tonga Online). The amendment to the Constitution followed a previous attempt by government through the Privy Council in an Order of Ordinance to ban the Taimi 'o Tonga, according to Senituli.

The Bill emerged in the wake of Chief Justice Gordon Ward's judgment on 26 May 2003 that the Ordinance passed by the King and the Privy Council on 4 April 2003 placing a further [fourth] ban on the Taimi ' $O$ Tonga was void. Later the same day the Chief Justice added a ruling, delivered in Chambers, placing a temporary injunction on another Ordinance passed by the King and the Privy Council on 16 May that purported to invalidate Taimi 'o Tonga's license [sic] to trade [fifth ban]. He further restrained the government, its 'servants or agents or otherwise howsoever' from revoking Taimi 'o Tonga's license until 'further Order of this Court'. (Senituli, 2003: Planet-Tonga online)

Though the amendment made in 2003 was judged to be unconstitutional, both amendments have yet to be repealed which can only be done through the Legislative Assembly. 


\title{
Case studies: The Niu Vakai and Taimi 'o Tonga newspapers
}

Tonga may be a constitutional monarchy but in reality the power to rule was mostly in the hands of the King, as indicated earlier. Terje Steinulfsson Skjerdal (1993) argued that,

\begin{abstract}
The media in an authoritarian system are not allowed to print or broadcast anything which could undermine the established authority, and any offence to the existing political values is avoided. The authoritarian government may go to the step of punishing anyone who questions the state's ideology. (Skjerdal, 1993: 3)
\end{abstract}

This was the case with both Niu Vakai and the Taimi 'o Tonga newspaper. The argument here is that, although Tonga may not be an authoritarian state, the environment and form of government and the country's socio-political structure does in some aspects reflect the authoritarian model.

The case studies of the Taimi 'o Tonga newspaper and the Niu Vakai emphasises what Siebert, Peterson and Scramm (1956, p. 2) argued that the press (or other media) in any country always takes on the 'form and colouration of the social and political structures within which it operates': 'Especially, it reflects the system of social control whereby the relations understanding of these aspects is basic to any systematic understanding of the press.'

The Taimi 'o Tonga newspaper was Tonga's most persecuted newspaper in modern history while Niu Vakai was the government's main opposition in the 19th century. Tonga's form of government certainly affects or has some sort of influence on the media as these case studies will show.

\section{The Niu Vakai}

The Niu Vakai newspaper was owned and published by a European, Robert Hanslip, who was an influential trader living in Tonga in the 19th century. The newspaper was first produced by hand in October 1881, but was later printed by Rev. James Egan Moulton, former headmaster of the Wesleyan Church-run school Tupou College, ${ }^{1}$ using the school's printing press. Niu Vakai was associated with a dissident movement of minor chiefs in the eastern district which was labeled by the King and his Prime Minister (Baker) the Mu'a Parliament. The movement was not an actual Parliament itself but was seen as a threat. This was due to the support they got from the nobles, traders and also the expatriate community, especially Hanslip, who, according to Campbell (2001, p. 104) was Baker's long time enemy. Rutherford 
(1977) claimed that these minor chiefs were eliminated under the government's new Land Act and no longer recognised by law. Hanslip saw the opportunity and advised the members of the Mu'a Parliament, assisting them with their petition to the King. It is thought that the Niu Vakai was established out of this movement. Hanslip was writing about the dissatisfaction of the Mu'a Parliament and also voiced concerns about some of the laws that Baker was imposing, not only on the Tongan people but also on the expatriate community who strongly disapproved of some of the laws which saw as Baker's doing. Tungi, one of the high chiefs of Mu'a, was an opponent of the King and supporter of the Mu'a Parliament but he was also in line to the throne. Hanslip saw an even bigger opportunity: should Tungi become King, he (Hanslip) would become his adviser.

The first edition of the Niu Vakai covered the grievances of the Mu'a Parliament and their petition to the King. The members of the Mu'a Parliament also gained support from the European community and the $\mathrm{Ha}$ 'a Havea chiefs who were the King's traditional rivals.

Hanslip was also active in collecting 2000 signatures for a petition to Queen Victoria to remove Baker from Tonga, which he forwarded to the British consul (Rutherford, 1977). The Mu'a Parliament members were arrested and charged. This gave Hanslip more to write about and he criticised the government with the support of letters to the editor, not only in the Niu Vakai but also in The Fiji Times.

In March 1882, the government established a Tongan-language newspaper, the Tonga Times, or Ko a Taimi 'o Tonga, to counter what was being printed in the Niu Vakai. Prince Wellington Ngu was the editor but, according to Rutherford (1977), the Ko a Taimi 'o Tonga was only providing Hanslip with more material to criticise.

In June 1882, Baker wrote to the British High Commissioner for the Western Pacific, Sir Arthur Gordon, asking to issue a writ of prohibition against Hanslip that would have allowed for his deportation from Tonga (Barney, 1974, p. 356). This was based on five types of complaints, made by Baker against Hanslip. This including inciting the natives against the King and his government, and this was all related to the articles published by the Niu Vakai newspaper. However on a visit to Tonga in July 1882, Sir Arthur signed a judgment that refused to find Hanslip 'to be dangerous to the peace and good order of the Western Pacific' (Ibid). 
Sir Arthur's decision was a blow to Baker and the government and it made them more determined to silence Niu Vakai. Hanslip was banned from parliamentary sessions which were one of Niu Vakai's major sources of information. According to Barney (1974, p. 355) it was during these sessions that the new press restriction laws were passed.

This was the first time that the free press provision of the 1885 Constitution was amended. This was approved by the Legislative Assembly and Privy Council and signed by King George Tupou I on the 23 October, 1882. 'On the same day, King George approved three Acts in apparent contradiction to the free press and free speech spirit of the Constitution (1) a Sedition Act; (2) Act

Table 1: Press law passage and publication dates in Tonga
\begin{tabular}{|l|c|c|}
\hline & Passed & Published \\
\hline Sedition Act & Oct 23, 1882 & Nov 22, 1882 \\
\hline Newspaper Printing & Oct 23, 1882 & Nov 22, 1882 \\
\hline Constitution & Oct 23, 1882 & April 16, 1883 \\
\hline Libel & Oct 23, 1882 & March 14, 1888 \\
\hline
\end{tabular}

Source: Barney [1974, p. 355]

to Regulate the Printing of Newspaper; and (3) a libel law' (Ibid). These Acts were no doubt directed at Niu Vakai, which was seen by Baker and the government as a threat. The Sedition Act provided for prison terms from two to 24 years for anyone who cursed or libeled the King, or who attempted to incite rebellion against the laws, or 'for any person who shall do anything to produce hatred or contempt to Government or the King'. The law could be violated by speaking, writing or printing (Ibid.).

The Act to Regulate the Printing of Newspapers required a permit from the Minister of Police in order to print and distribute a newspaper. To get a permit, the publisher was also required to find two bondsmen with $£ 500$ each to act as guarantors.

Hanslip was deprived of his printing facilities. Barney (1974, p. 357) suggested that this was because Niu Vakai was assisted by the principal of the Methodist School, Rev. Moulton, who was Baker's most vocal critic. Moulton was prosecuted on various charges related to the use of the printing press, including seditious actions towards the Tongan government and the King, and was later found guilty on some of them. 


\section{The Taimi 'o Tonga}

When the newspaper was established in 1989 it was to be Tonga's first independent newspaper in contemporary Tonga. It was first published in Tonga before being moved to Auckland, New Zealand, for mostly financial reasons, including access to the Tongan diaspora in New Zealand, Australia and United States. The Taimi 'o Tonga was published by the Lali Media Group but it is now owned and published by the Taimi Media Network, owned by Kalafi Moala, a Tongan who is also an American citizen and his wife Suliana.

From the beginning of Taimi 'o Tonga, Moala claimed that it was established as an alternative media outlet, to give the people the real news and views not provided by the established government media.

The newspaper covered news and issues that government-owned media would never have covered. These included the sale of Tongan passports, the activities of some of the King's business partners, and the overpayment of members of Parliament, among other issues.

The Taimi 'o Tonga was seen as a nuisance to the government and the royal family, including then minister of police Clive Edwards. The newspaper was banned from government press conferences and government departments were told not to give information to the Taimi 'o Tonga. According to Kalafi Moala, as more measures were taken against the paper, the more leaked information it received from people inside the government (Moala, 2002, p. 48). The paper has historically presented views antagonistic to many government ministries and was a staunch supporter of the democratic movements in Tonga, although it does not represent or directly endorse any single candidate during elections.

In February 1996, the Taimi 'o Tonga's assistant news editor, Filokalafi 'Akauola, was arrested for publishing a letter to the editor criticising the Minister of Police. Ironically, the charge was made under the libel law introduced by Shirley Baker back in 1882 when he amended the Constitution (Barney, 1974, p. 357).

Also in the same year, the Taimi 'o Tonga newspaper had published an article on a motion tabled in Parliament to impeach the then Minister of Justice, the Hon. Tevita Tupou, for leaving for the Atlanta Olympics without permission from Parliament.

On his return, Tupou read about the impeachment in the Taimi, and called the Parliament office because he was unaware of the impeachment. He was told that the Legislative Assembly had not received any motion and that the 
article was inaccurate. Parliament officials checked who made the leak and 'Akilisi Pohiva voluntarily confessed to leaking the information. It was later found that the motion was still with the Acting Speaker of the House and was yet to be submitted or tabled.

The three defendants were summoned by Parliament where their fates were to be decided. The three defendants Kalafi Moala, Filokalafi 'Akau'ola and 'Akilisi Pohiva were charged under Clause 70 of the Constitution where it states;

....if anyone speaks disrespectfully or acts in a dishonourable way in Parliament, the Parliament is authorised to jail this person for 30 days. And while the house is in session, someone writes something, deceiving the House or threatening a member ... the person will be allowed to be jailed for 30 days. (Clause 70, Tongan Constitution)

The legislative assembly voted 19 to two in favour of a guilty verdict and sentenced the defendants to 30 days in jail. The jailing made headlines throughout the Pacific and attracted huge media attention, both in Tonga and abroad. International media organisations and human rights groups called for their release, condemning the move as a threat to press freedom (see Moala, 1996; Robie, 1996; and Pohiva, 1996). The three defendants were later released after being in prison for 26 days. In his ruling, Chief Justice Hampton stated:

The conclusion I have reached therefore, is that the procedures adopted were unfair. They were not in accordance with the Constitution or with the Legislative Assembly's own Rule made under the Constitution.... it follows that I determine that the detention of the applicants in these circumstances is not lawful and I make an order that each of them be released forthwith from detention. (Supreme Court of Tonga Moala \& ors v Minister of Police (No 2) [1996] Tonga LR 207)

This was hailed as a victory for the Taimi 'o Tonga and freedom of the press but in 2003 the newspaper was banned from Tonga under Section 34 of the Customs and Excise Act. The Chief Commissioner of Revenue issued a notice prohibiting the import of the newspaper citing three main reasons;

1. Taimi 'o Tonga is a foreign paper, owned and published by a foreigner 
2. Taimi 'o Tonga is a foreign concern with a political agenda

3. Taimi 'o Tonga's continuous standard of journalism is unacceptable (cited by Robie, 2003).

The 'foreign ownership' that the ban was referring to was Moala's American citizenship. At this time, the law allowing dual citizenship was not in place. It could be argued that the concern of the government over the Tongan media was partially genuine, meaning that the standard of journalism was very low, and there was no mechanism outside government to regulate and deal with grievances against the media. But the way the government went about doing this was seen as unlawful.

The Taimi 'o Tonga at the time, like most of the independent media outlets in Tonga, did not have qualified journalists with formal media training. The majority of the journalists received their training on the job. In an interview on Radio Tonga, Kalafi Moala admitted to the fact that journalists working for the independent media did not have the qualifications that government journalists have, and this made their work more difficult. The way in which issues are covered at times without balance could be attributed to the lack of experience.

After the Supreme Court overturned the ban, declaring it unconstitutional, the government imposed another ban on the Taimi 'o Tonga under the Publication Act. The Supreme Court again ruled that the ban that was illegal. However, the government introduced the Media Operators Act, the Newspaper Act and an amendment to the Constitution in an apparent effort to tighten official control over the media. This was another blow for the Taimi ' $o$ Tonga, for its survival and also for the freedom of the press. The Newspaper Act required that all publications be licensed and the Media Operator's Act stated that foreigners could not own more than a 20 percent stake in a media company. The Media Operator's Act was seen by many as a direct attempt by the government to have more control of the media and to silence the Taimi ' $o$ Tonga. Kalafi Moala, editor-in-chief of the Taimi 'o Tonga newspapers, described the amendment as childishness. 'And even though these legislations [sic] were directed at the Taimi 'o Tonga newspaper, it ended up affecting other newspapers or print media that are sometimes critical of government policies and practice' (Moala, 2006b).

The government set a 31 January 2004 deadline for licence registration, and those who dared to violate the Acts were punishable by a fine of approximately US\$5,200 or up to one year's imprisonment. After the deadline, 
only church-owned publications, government-owned publications and a progovernment newsletter were granted licences. All the independent newspapers, including the Taimi 'o Tonga, the quarterly news magazine Matangi Tonga and Kele'a, a newspaper owned by pro-democracy Member of Parliament Pohiva, were denied licences.

Tongan journalists and overseas media organisation accused the government of denying licenses to publications they feared would report critically on state affairs.

The ban on the Taimi 'o Tonga was felt throughout Tonga. People were starved of alternative news and views. During the ban, the Taimi 'o Tonga was still in circulation in New Zealand, Australia and the United States. According to Moala (K. Moala, personal communication, 2007), the sales increased in New Zealand because people were sending copies to their families and friends in Tonga. The ban led to calls from media organisations, human rights organisations and politicians from New Zealand and Australia to lift it.

'Alani Taione, a New Zealand resident, confronted the government's ban. He flew to Tonga for his father's funeral and on arrival he openly distributed copies of the banned newspaper at the airport, even giving some to customs officers and some people at the airport. He was quickly arrested by the police and charged with the importation and distribution of the banned newspaper. Thousands of people including religious leaders marched with a petition to the King demanding he lift the ban. The case was referred to the Supreme Court and Taione along with the three other defendants challenged the legality of ban on the newspaper. The case also put into question the Amendment to Clause 7 of the Constitution, the Media Act and the Newspaper Operators Act.

The Supreme Court case was heard on the 21 June 2004 and concluded on the 15 October 2004. After hearing submissions from both the defendants and the plaintiffs, the Chief Justice, Robin Webster, delivered a lengthy verdict. Prior to this particular court case, there were other court cases between government and the Lali Media Group which published the Taimi 'o Tonga at the time. In his verdict, Chief Justice Webster outlined in chronological order the events and how the legislation in question came into force. In his concluding remarks, he said:

I found that both Acts were inconsistent with Clause $7 \ldots$ and therefore void in terms of Clause 82 of the Constitution. I very much regret having to make such a finding in relation to legislation, which has had 
the approval of the Legislative Assembly, the Cabinet, the Privy Council and His Majesty the King, but it is the clear duty of this Court under the Constitution to do so and thus to uphold the Constitution. (Supreme Court of Tonga, Taione vs. Kingdom of Tonga, 2003)

Chief Justice Webster painted a vivid picture of the essence of freedom of expression when he quoted Voltaire: 'I disapprove of what you say, but I will defend to the death your right to say it.' (Ibid.)

This was a blow to the government and a victory not only for the Taimi 'o Tonga but for media freedom. It was not long after the trial that Clive Edwards, the Minister of Police, who was accused by both Moala and the media of being the main instigator of the legislation, was forced to resign. In an exchange of words on Matangi Tonga Online, the then Crown Prince Tupouto'a (now King Geoge V) accused Edwards of being the one behind the move to introduce the new media law, after Edwards had first accused the crown prince of initiating the move.

The truth is that Clive Edwards believed himself clever enough to harness the Constitution in his personal vendetta against the Taimi ' $O$ Tonga newspaper and its editor, Kalafi Moala. He failed in this endeavour because of his ignorance of the law. Proof of this unfamiliarity with court procedure is that he was unable to understand that changes to the Constitution should be attended by changes in the judge's rules if they are at all to succeed. This is why his measure failed-something I probably forgot to mention to him at the time. (Tupouto'a, Matangi Tonga Online, 2005)

Moala agreed with the Crown Prince and said that he knew that Edwards was 'after him' (Moala) personally:

So we have always known that and I am quite thrilled, in fact, that the Crown Prince or someone from the royal family and high up in the government is able to come up with that. (Radio New Zealand International Online, 26 January 2005)

Both the claims by the Crown Prince and Moala about Edwards' personal vendetta against Moala appear to be supported by an earlier interview with Edwards on Radio Australia about the Taimi 'o Tonga. 
If you have a rag that's scurrilous all the time and you have to try and correct it all the time, why should we put up with it? You tell me, why should we put up with a paper that has no standing here? (Bradford, 2003. Radio Australia Online)

\section{Discussion}

The cases of the Niu Vakai and the Taimi 'o Tonga have both suggested that little or nothing has changed in the attitude of the ruling elite towards the opposing media. In traditional Tongan culture, criticising authorities was unprecedented and was never head of until the arrival of the media. It was probably a shock to Baker and his government that the Niu Vakai was moving from the tradition of faka'apa' $a a^{2}$ and voiced the chiefs and people's concern in his newspaper. However this could also be attributed to Hanslip's influence as an European and his personality.

In the Taimi 'o Tonga's case, though Kalafi Moala was born and raised in Tonga, he spent a lot of his time abroad and in different countries. His Western education background and exposure to democratic ideologies influenced his approach and distancing himself from 'lapdog journalism' to the more objective Western journalism. This Western influence was evident in his newspaper's strong line of opposition to the authorities and the push for democracy.

Though a century apart, the form of government ruling Tonga has not changed. One of the important points to note in both cases is that kings, George Tupou I in the Niu Vakai's case and Tupou IV in the Taimi 'o Tonga, were never at the forefront of the debate. Baker was the most vocal and opponent of the Niu Vakai and the amendments made to the Constitution were attributed to him. Barney (1974) argued that it was evident that the amendment was done in Baker's favour.

.... [T] extend the protective umbrella to include criticism directed at either holders of high position or members of His Majesty's government. In either case it seems the laws were intended primarily to subdue criticism of the King's European premier [Baker]. Barney (1974, p. 357).

In the Taimi 'o Tonga's case, it was former Minister of Police Clive Edwards who was accused of being responsible for introduction of the media laws. This was revealed by the then Crown Prince Tupouto'a, who is now King George V, in a letter to the editor on the Matangi Tonga Online, where he 
accused Clive of being the one behind the amendment. This was a claim that Edwards denied.

I read in Clive Edwards's interview that he accused me of proposing the Media Operator's Act. This is wholly untrue but as Edwards is running for Parliament his wild accusations are, I suppose, understandable. I was opposed to the anti-media laws on the grounds that they were not our style of doing things in this country. (Tupouto'a quoted in Matangi Tonga Online, 21 January 2005)

The Crown Prince in another letter accused Clive Edwards of having a personal vendetta against the Taimi 'o Tonga owner, Kalafi Moala. The irony here, as Edwards later revealed, was that Tupouto'a was the Regent at time when the Acts were presented to the Privy Council. However Tupouto'a (2005) in reply suggested that the ministers were united in agreeing for the proposed Media Bill a day before Parliament voted on it.

However, the Privy Council presented me with a unanimous front in favour of the legislation; I felt it was not the place of the Regent to go against their wishes. Had the dissenting minister stuck to his guns, I might have felt confident in ordering the entire matter dropped and the legislation withdrawn. (Tupouto'a in Matangi Tonga Online, 25 January 2005)

The power of the monarchy also poses an interesting question. The monarch in Tonga has often been referred to as a 'dictator' or an 'absolute monarch'. These two cases suggest that the monarchy does not act on its own but on advice from his ministers and advisers. Tupou I was acting on Baker's advice and, as Tupouto'a suggests in his letter, despite his opposition to the media legislation, he had to act upon the minister's advice. Clive Edwards was the most vocal promoter of the Media Bill and was able to win support from the other ministers for the Bill which the Regent did not wish to vote against, even though he later revealed he was opposed to it. Because the monarchy is well protected by the Constitution, it could be argued that in both cases, those who were close to the monarch were also trying to either seek vengeance over their political critics or try to protect themselves as well. Kings George Tupou I and Taufa'ahau Tupou IV never went public and criticised the media in either cases. In fact, when Kinga Taufa'ahau IV was premier 
he wrote a letter to the government-owned Tonga Chronicle, defending the newspaper against criticism from Parliament.

The Taimi 'o Tonga newspaper and the Niu Vakai were both seen as mouthpieces for the opposition or dissident voices. A Fiji Times contributor cited in Barney (1974) describes the impact of the Niu Vakai newspaper:

In Parliamentary parlance, it was the mouthpiece of his Majesty's opposition in Tonga and a very remarkably warm opposition it constituted....... From a Tongan standpoint it was, however admirably calculated to attain its objective, and it became a weapon which its writer used to very considerable advantage. (Barney, 1974, p. 355)

The parallel here is that both newspapers were deemed to be mouthpieces of the opposition to the King and his government. The Taimi 'o Tonga was accused of fronting for the pro-democracy movement and their support was no secret, and it was the same with the Niu Vakai's support for the discontented chiefs and their supporters, especially the expatriate community in Tonga. Both the Taimi 'o Tonga newspaper and the Niu Vakai were taken to the highest court in the country where they were both freed. Sir Arthur Gordon, who was sent from the Colonial Office in Fiji, ruled against deporting Hanslip for allegedly inciting the natives against their King and government, a charge made by Baker. The Times of Tonga on the other hand was banned several times and the Supreme Court's decision went in their favour when Justice Webster ruled that the Media Legislation were un-Constitutional.

In the case of the Taimi 'o Tonga according to Robie (2004a, p. 112) the new Clause 7 effectively overturned the constitutional guarantee of a free press and the new Clause 56A was a direct attack on the existing constitutional position of the law courts. 'The intended effect of Clause 56A is to nullify the role of the courts in constitutional rulings because there would no longer be anybody with the power and authority under the Constitution to adjudicate. This would effectively "put an end to the rule of law in Tonga" (cited in Robie, 2004a, p. 113)

Both the Niu Vakai and the Taimi 'o Tonga newspapers were supporting anti-government movements. The Niu Vakai supported the Mu'a Parliament, which was seen at the time as a threat to government. The underlying cause was the fight between Hanslip of the Niu Vakai and the premier, Shirley Baker. In the case of the Taimi ' $o$ Tonga, the newspaper supported the pro-democracy 
movement, which was the greatest threat to the government. The then Minister of Police, Clive Edwards, was viewed by many as the man behind the ban on the Taimi 'o Tonga and also the introduction of the Media Operators Act and the Newspaper Act. However, Clive Edwards denied all these accusations of him having a personal vendetta against Moala and the Taimi 'o Tonga. Edwards was accused by both Moala and the then Crown Prince of having a personal vendetta against Moala and the Taimi 'o Tonga newspaper.

One of the charges made against the Taimi 'o Tonga was about their standard of journalism, which officials deemed unacceptable. This was clearly an excuse by the government because the Taimi 'o Tonga was not alone. One of the greatest challenges to the media in Tonga is the lack of experience among the media staff. When Kalafi Moala was asked in an interview about some of the problems faced by the media, he mentioned their lack of experience. Pesi Fonua, editor of the Matangi Tonga Online, and president of the Media Council of Tonga, went even further when he said:

The biggest threat to media freedom in Tonga at the moment is the media itself, simply because it has not raised the standard of journalism in the country, and worse, engaged in running down each other instead of presenting fair reporting on what is happening [and] instead of campaigning and deliberately confusing the poor people. (P. Fonua, personal communication, 2007)

As Siebert, Peterson and Schramm (1963) argue, under the authoritarian model the government will take any steps possible to punish anyone that opposes it. The government tried every possible means to silence the Taimi 'o Tonga-by imposing five different bans, one after the other. Also, on the day the Supreme Court declared the ban on the newspaper illegal, the government, through the Privy Council, passed two special Ordinances which were later again declared illegal by the courts.

Apart from what happened in 2003, the media in Tonga have indeed been largely free from any government persecution. As we have seen, in the case against the Taimi ' $o$ Tonga, the judicial system has been the main defender of the freedom of the media. The Taimi 'o Tonga was not the only media outlet that suffered under the section of the Act dealing with foreign ownership.

Culture is often seen as challenging the freedom of the media. This is not just the case in Tonga but throughout the Pacific. In Tongan society there is the 
King, then the nobles, and then the commoners below, including journalists. Journalists are often caught in the middle, wondering whether to report issues which are culturally sensitive. These include issues that involve the royal family or nobles. Such issues are often not covered because of not only fear of repercussions but also because of faka'apa'apa (respect). An unpublished dissertation by Paul O'Connell cited in Robie (2004b, 30) suggested that:

Whether culture is being misused to censor freedom of speech or whether it has tacit effect as self-censorship, it must nonetheless be acknowledged as a factor preventing democratic freedom of expression. (O'Connell, in Robie, 2004b, 30)

As mentioned above, both the Niu Vakai and the Taimi 'o Tonga were attacked for their influence on local culture. In conflict situations, the authorities often use culture as a pretext when trying to silence anyone who dares to speak against the establishment.

These cases also highlight the impact that the media can have on government policy. This has often been challenged on the basis that the extent of the media's impact on government policy has not been tested fully. However it could be argued that the government's media policy and the amendment to the Constitution was directly a reply or attack on the opposing media critics.

\section{Notes}

1. A college established by the Wesleyan Missionaries in 1886 .

2. Respect. In this context the commoners were expected to do what they are told without questioning, so questioning the authorities and voicing their concerns were unheard of.

\section{References:}

Barney, R. (1974). The Journal of Polynesian Society, 83(3); pp 349-260.

Bradford, G. (2003). Tonga-Royal Family, Foreign Correspondent, Radio Australia. Retrieved 12 January 2008).

Castells, M. (2000a) The information age: economy, society and culture (Updated edition). Oxford: Blackwell.

Harrison, R. E. (2003). Kingdom of Tonga: Proposed Amendments to Constitution. Report prepared for Kalafi Moala, 4 June 2003. Cited in Robie D. (2004a). The sword of Damocles in the South Pacific: Two media regulatory case studies. Pacific Journalism Review, 10(1); pp. 103-122. 
His Majesty King George Tupou V, A monarch for a time of change. (2008, July 28). Prime Minister's Office Online. Retrieved on 12 October 2008 at: www.pmo.gov.to Latukefu, S. (1975). The Tongan constitution. Nuku'alofa: Tonga Traditions Committee Publication.

Latukefu, S. (1974). Church and state in Tonga. Canberra: Australia National University Press.

Lawson S. (1996). Tradition versus democracy in the South Pacific. Cambridge, UK: Cambridge University Press.

Moala, K. (2009). In search of the friendly islands. Honolulu, HI: Pasifika Foundation Press, and Auckland: Pacific Media Centre.

Moala, K. (2002). Island kingdom strikes back. The story of an independent island newspaper-Taimi 'o Tonga. Auckland: Pacmedia.

Moala, K. (2000). Tonga and the independent press. Pacific Journalism Review. 6(1), pp 59-62.

Moala \& ors v Minister of Police (No 2) [1996] Tonga LR 207, Supreme Court of Tonga. Retrieved on 27 June 2008, from: www.paclii.org/to/cases/TOSC/2004/47. html

Moala, K. (1996). We didn't get a fair trial. Pacific Journalism Review, 3(2); pp. 13-14. Pohiva, 'A. (2002) Media, justice in Tonga. Pacific Journalism Review, 8; pp. 96-104.

Pohiva, 'A. (1996). From 'Samuela 'Akilisi Pohiva. Pacific Journalism Review, 3(2); pp. 17-18.

Robie D. (2004a). The sword of Damocles in the South Pacific: Two media regulatory case studies. Pacific Journalism Review, 10(1); pp. 103-122.

Robie, D. (2004b). Mekim nius: South Pacific media, politics and education. Suva, Fiji: University of the South Pacific.

Robie, David (2003, March 15). Banned newspaper publisher calls for 'fight for justice'. Pacific Media Watch. Retrieved on 22 September 2008, from: www. asiapac.org.fj/cafepacific/resources/aspac/tongan3983.html

Robie, D. (1996). The contempt case of the 'Tongan three'. Pacific Journalism Review, 3(2); pp. 10-19.

Robinson, P. (2001) Theorising the influence of media on world politics. In models of media influence on foreign policy, European Journal of Communication SAGE Publications, 16(4); pp. 523-544.

Rutherford N. (1977). Friendly islands: a history of Tonga: Oxford, UK: Oxford University Press.

Siebert, F. S., Theodore P., and Schramm, W. (1956). Four theories of the press. Chicago: University of Illinois Press.

Taione vs Kingdom of Tonga, 2003, Supreme Court Decision.

The Government of Tonga prohibits the import of foreign newspaper Taimi ' $o$ Tonga. (2003, February 2007). Tonga Government Press Release. Retrieved on 24 February 2009, from: http://nomoa.com/news/Taimi_\%27o_Tonga_Imports_ Banned 


\section{MEDIA FREEDOM IN OCEANIA}

Tonga Parliament passes controversial amendment (2003, October 16). Radio New Zealand International. Retrieved on 26 January 2009, from: www.rnzi.com

Tonga newspaper publisher thrilled that Crown Prince is speaking out over failed media law change (2005, January 26), Radio New Zealand International. Retrieved on 24 February 2009, from: www.rnzi.com

Tongan coronation events begins, BBC online, 30 July 2008. Retrieved on 17 October 2009, from: www.bbc.co.uk

Tongan police minister lays complaint over Taimi 'o Tonga story (2003, July 11). Radio

New Zealand International. Retrieved on 17 January 2009, from: www.rnzi.com Tupouto'a. (2005, January 25). Media Bills had become a cause célèbre, Matangi Tonga Online. Retrieved on 17 January 2009, from: www.matangitonga.to Webster, Chief Justice (2004, October 15). The High Court Decision

Sione Fatanitavake Vikilani is a doctoral candidate at the Ritsumeikan Asia Pacific University, Japan, and a former television and Radio Tonga news editor. sione.vikilani@gmail.com

\section{TIMARU 2010}

Journalism Education Association of New Zealand Annual Conference, 2 and 3 December

\section{Theme:What Editors Want}

Partners programme being developed for those who wish to use the conference as the launch for a holiday in the Mainland.

There are flights directly into Timaru from Wellington. Alternatively,

fly to Christchurch and drive (two hours).

The JEANZ AGM will be held on 3 December

Convenor: Peter O’Neill Ph: +64 36840845 Email: peter.oneill@aoraki.ac.nz

Abstracts: Jim Tully Ph: +64 3 364288I Email: jim.tully@canterbury.ac.nz

Registration: Janine Burgess Ph: +64 36848240 Email: janine.burgess@aoraki.ac.nz 
Copyright of Pacific Journalism Review is the property of Auckland University of Technology and its content may not be copied or emailed to multiple sites or posted to a listserv without the copyright holder's express written permission. However, users may print, download, or email articles for individual use.

http://www.aut.ac.nz/depts/commstud/journ/pjrsubs.shtml 